\title{
NOTE
}

\section{Beryllium-7 deposition at Fayetteville, Arkansas, and excess polonium-210 from the 1980 eruption of Mount St. Helens}

\author{
S. C. Lee, A. I. Saleh ${ }^{1}$, A. D. Banavali ${ }^{2}$, L. Jonooby and P. K. Kuroda \\ Department of Chemistry, University of Arkansas, Fayetteville, Arkansas 72701 U.S.A.
}

(Received June 11, 1985: Accepted July 21, 1985)

\begin{abstract}
Radiochemical measurements of ${ }^{7} \mathrm{Be}$ were carried out for a total of 246 individual rain and snow samples collected at Fayetteville $\left(36^{\circ} \mathrm{N}, 94^{\circ} \mathrm{W}\right)$, Arkansas, during the period between September 1979 and December 1984. A sharp increase in the ${ }^{210} \mathrm{Po} /{ }^{7} \mathrm{Be}$ ratio in rain observed during the winter and spring months of $1980-1981$ was attributed to the fallout of excess ${ }^{210} \mathrm{Po}$ from the May 1980 eruption of Mount St. Helens.
\end{abstract}

\section{INTRODUCTION}

The importance of ${ }^{7} \mathrm{Be}$ as a radioactive tracer in the study of atmospheric phenomena has long been well recognized (see, for example, Lal and Peters, 1967; Wogman et al., 1968; Perkins et al,, 1970; Husain et al., 1977; Dutkiewicz and Husain, 1979; Furukawa and Kojima, 1982). Measurements of ${ }^{7} \mathrm{Be}$ concentrations in individual rain and snow samples were initiated in our laboratories in the fall of 1979 and the analyses of all the samples collected during a five-year period 1979-1984 have been completed, except for the fact that the measurements were not carried out during a period of about 8 months in 1983. While this study was in progress, the eruption of Mount St. Helens occurred in May 1980 and it was noted that there was a sharp increase in the ${ }^{210} \mathrm{Po} /{ }^{210} \mathrm{~Pb}$ ratio in rain during the winter and spring months of 1980-1981 (Kuroda et al., 1984). An increase in the ${ }^{210} \mathrm{Po} /$ ${ }^{7} \mathrm{Be}$ ratio in rain was also noted during the course of the study on ${ }^{7} \mathrm{Be}$ and these results indicated that we are dealing here with an atmospheric injection of excess ${ }^{210}$ Po from the volcanic eruption. An estimate of the amount of excess ${ }^{210}$ Po released into the atmosphere by the 1980 eruption of Mount St. Helens is presented in this report.

\section{EXPERIMENTAL}

The rain and snow samples were collected by means of a sampling system located on the roof of the Chemistry Building of the University of Arkansas, which is located at Fayetteville $\left(36^{\circ} \mathrm{N}\right.$, $94^{\circ} \mathrm{W}$ ), Arkansas. The amount of rainwater used for the analysis of ${ }^{7} \mathrm{Be}$ ranged from 10 to 40 liters. The rain samples collected during the period between September 1979 and December 1981 contained appreciable amounts of fission products from the Chinese nuclear weapons tests. Since the gamma-rays from fission products such as ${ }^{103} \mathrm{Ru},{ }^{106} \mathrm{Ru},{ }^{125} \mathrm{Sb}$ and ${ }^{140} \mathrm{La}$ are known to mask the $477.6 \mathrm{KeV}$ peak of ${ }^{7} \mathrm{Be}$, we have decided to separate and radiochemically purify the beryllium fractions before they were counted. The radiochemical purification procedure used for the analyses of ${ }^{7} \mathrm{Be}$ was that described by Buchanan (1958). The purification procedure was omitted, however, for the samples collected after January 1, 1982, when the levels of fission product activities in the atmosphere became extremely low.

1 Present address: Chemistry Department, Faculty of Science, University of Elfeteh, Tripoli, Libya.

2 Present address: Division of Nuclear Radiochemistry, U.S. Testing Company, Inc., 2800 George Washington Way, Richland, Washington 99352, U.S.A. 


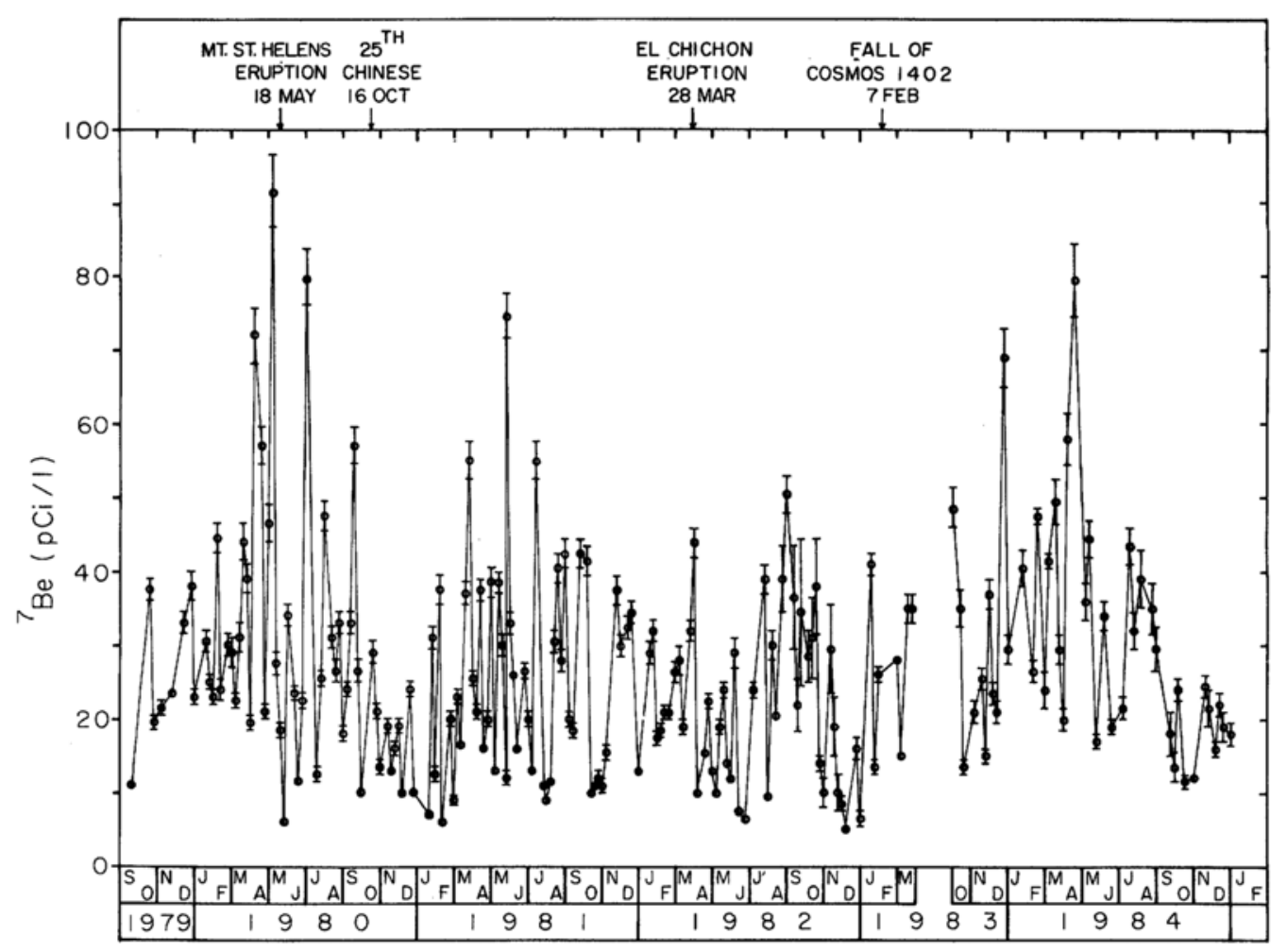

Fig. 1. The concentrations of ${ }^{7} \mathrm{Be}$ in individual rain and snow samples collected at Fayetteville $\left(36^{\circ} \mathrm{N}\right.$, $94^{\circ} \mathrm{W}$ ), Arkansas, during the period between September 1979 and December 1984.

The radioactivity measurements were carried out with Ortec $\mathrm{Ge}(\mathrm{Li})$ gamma-ray detector. An Ortec preamplifier and an Ortec 572 main amplifier were used in conjunction with a Nuclear Data 575 ADC and a Nuclear Data 600 analyzer. The detector photopeak response curve was established with a set of calibrated gamma-ray sources of known activities, consisting of ${ }^{57} \mathrm{Co},{ }^{60} \mathrm{Co},{ }^{85} \mathrm{Sr},{ }^{88} \mathrm{Y},{ }^{109} \mathrm{Cd},{ }^{113} \mathrm{Sn}$, ${ }^{137} \mathrm{Cs},{ }^{139} \mathrm{Ce}$ and ${ }^{203} \mathrm{Hg}$ obtained as a mixed source in solution form and point source from the National Bureau of Standards.

\section{Results AND Discussion}

Figure 1 shows the seasonal variation of the concentrations of ${ }^{7} \mathrm{Be}$ in individual samples of rain and snow collected at Fayetteville, Arkansas during the period between September 1979 and December 1984. The dates of the eruptions of Mount St. Helens (18 May 1980) and E1
Chichon volcano (28 March 1982), and also the 25th Chinese nuclear test (16 October 1980) and the fall of the nuclear-powered Soviet satellite Cosmos-1402 (7 February 1983) are also shown in Fig. 1. The ${ }^{7} \mathrm{Be}$ concentrations in individual rain and snow samples fluctuated markedly. The maximum value of $(91.3 \pm 4.9)$ pCi per liter was observed in the rain of 5 May 1980 and the minimum value of $(4.9 \pm 0.6) \mathrm{pCi}$ per liter in the rain of 10 December 1982.

Table 1 shows the bi-monthly average concentrations $(\overline{\mathrm{C}})$ of ${ }^{7} \mathrm{Be}$ in rain calculated by the equation

$$
\overline{\mathrm{C}}=\frac{\Sigma \mathrm{R} \cdot \mathrm{C}}{\Sigma \mathrm{R}}
$$

where $\mathrm{R}$ is the amount of individual rainfall and $\mathrm{C}$ is the concentration of ${ }^{7} \mathrm{Be}$ in individual samples of rainfalls which occurred during a two-month period.

Matsunami et al. (1974) have reported that 
Table 1. Bimonthly and annual average concentrations of ${ }^{7}$ Be in rain at Fayetteville, Arkansas, during the period between September 1979 and December 1984..$\left.^{*}\right)$

\begin{tabular}{|c|c|c|c|}
\hline $\begin{array}{l}\text { Year and } \\
\text { month }\end{array}$ & $\begin{array}{l}\text { Bimonthly } \\
\text { total rainfall } \\
(\mathrm{mm})\end{array}$ & $\begin{array}{l}\text { Bimonthly average } \\
\text { concentration } \\
\text { (pCi/l) }\end{array}$ & $\begin{array}{c}\text { Annual average } \\
\text { concentration } \\
(\mathrm{pCi} / 1)\end{array}$ \\
\hline 1979 & & & \\
\hline Sep. -Oct. & 44.45 & 18.6 & \\
\hline $\begin{array}{c}\text { Nov. -Dec. } \\
1980\end{array}$ & 110.74 & 27.0 & \\
\hline Jan. -Feb. & 44.08 & 25.5 & \\
\hline Mar. -Apr. & 164.98 & 30.3 & \\
\hline May -June & 251.34 & 21.8 & 23.3 \\
\hline July -Aug. & 30.48 & 27.3 & \\
\hline Sep. -Oct. & 161.56 & 24.3 & \\
\hline $\begin{array}{c}\text { Nov. -Dec. } \\
1981\end{array}$ & 112.02 & 12.8 & \\
\hline Jan. -Feb. & 98.88 & 10.8 & \\
\hline Mar. -Apr. & 163.72 & 25.6 & \\
\hline May -June & 421.12 & 17.5 & 17.3 \\
\hline July -Aug. & 263.39 & 15.6 & \\
\hline Sep. -Oct. & 222.61 & 13.6 & \\
\hline $\begin{array}{c}\text { Nov. -Dec. } \\
1982\end{array}$ & 45.46 & 26.7 & \\
\hline Jan. -Feb. & 183.7 & 20.4 & \\
\hline Mar. -Apr. & 130.3 & 20.3 & \\
\hline May -June & 533.7 & 10.3 & 14.5 \\
\hline July -Aug. & 87.4 & 24.9 & \\
\hline Sep. -Oct. & 80.5 & 21.9 & \\
\hline $\begin{array}{c}\text { Nov. -Dec. } \\
1983\end{array}$ & 379.0 & 11.7 & \\
\hline Jan. -Feb. & 58.3 & 26.7 & \\
\hline Mar. -Apr. & - & - & \\
\hline May -June & - & - & \\
\hline July -Aug. & - & - & \\
\hline Sep. -Oct. & - & - & \\
\hline $\begin{array}{c}\text { Nov. -Dec. } \\
1984\end{array}$ & 169.2 & 23.8 & \\
\hline Jan. -Feb. & 104.9 & 26.3 & \\
\hline Mar. -Apr. & 276.6 & 42.9 & \\
\hline May -June & 212.8 & 27.5 & 27.8 \\
\hline July-Aug. & 120.8 & 35.6 & \\
\hline Sep. -Oct. & 252.0 & 18.7 & \\
\hline Nov. -Dec. & 282.7 & 18.7 & \\
\hline
\end{tabular}

(*) Total rainfall and an overall average ${ }^{7}$ Be concentration in rain for a 56-month period from 1979 to 1984 were $5006.7 \mathrm{~mm}$ and $20.5 \mathrm{pCi}$ per liter.

the annual average rainfall in Osaka $\left(35^{\circ} \mathrm{N}\right.$, $\left.136^{\circ} \mathrm{E}\right)$, Japan, was $1,196 \mathrm{~mm}$ during 1970 -1973 and the average ${ }^{7} \mathrm{Be}$ concentration in rain was $5.7 \times 10^{6}$ atoms per liter. The annual average rainfall in Fayetteville $\left(36^{\circ} \mathrm{N}, 94^{\circ} \mathrm{W}\right)$, Arkansas, for the period 1980-1984, on the other hand, was $1,156 \mathrm{~mm}$ and the average ${ }^{7} \mathrm{Be}$ concentration in rain was $5.0 \times 10^{6}$ atoms per liter. The annual deposition of ${ }^{7} \mathrm{Be}$ at Fayetteville, Arkansas, can be calculated from our data to be $5.2\left(\mathrm{dpm} / \mathrm{cm}^{2} / \mathrm{y}\right)$. This value is in excellent agreement with the reported values of 5.5 $\left(\mathrm{dpm} / \mathrm{cm}^{2} / \mathrm{y}\right)$ at Chilton $\left(51^{\circ} \mathrm{N}\right)$ and $5.2(\mathrm{dpm} /$ $\left.\mathrm{cm}^{2} / \mathrm{y}\right)$ at Milford Haven $\left(51^{\circ} \mathrm{N}\right)$, England (Peirson, 1963) and is comparable to the reported values of $4.3\left(\mathrm{dpm} / \mathrm{cm}^{2} / \mathrm{y}\right)$ at Westwood $\left(41^{\circ} \mathrm{N}\right)$, N. J., (Walton and Fried, 1962), 9.5 $\left(\mathrm{dpm} / \mathrm{cm}^{2} / \mathrm{y}\right)$ at Rijswijk $\left(52^{\circ} \mathrm{N}\right)$, Netherlands (Bleichrodt and Van Abkoude, 1963), 7.6 (dpm/ $\mathrm{cm}^{2} / \mathrm{y}$ ) at Bombay $\left(19^{\circ} \mathrm{N}\right)$, India (Lal et al., $1979)$, and $8.1\left(\mathrm{dpm} / \mathrm{cm}^{2} / \mathrm{y}\right)$ at Quillayute $\left(49^{\circ} \mathrm{N}\right)$, Washington (Crecelius, 1981). It is worthy of note here, however, that Turekian et al. (1983) have recently reported the values of $17.1\left(\mathrm{dpm} / \mathrm{cm}^{2} / \mathrm{y}\right)$ at Bermuda $\left(33^{\circ} \mathrm{N}\right)$ and $22.7\left(\mathrm{dpm} / \mathrm{cm}^{2} / \mathrm{y}\right)$ at New Haven $\left(41^{\circ} \mathrm{N}\right)$, Connecticut.

Figure 2 shows a comparison of the variations of the bi-monthly average ratios of ${ }^{90} \mathrm{Sr} /$ ${ }^{7} \mathrm{Be}$ in rain at Fayetteville, Arkansas, during the period of $1979-1982$. The ${ }^{90} \mathrm{Sr}$ and ${ }^{210} \mathrm{Po}$ data were taken from the reports of Burchfield et al. (1982), Burchfield and Kuroda (1983), and Kuroda et al. (1984). A marked increase in the ${ }^{90} \mathrm{Sr} /{ }^{7} \mathrm{Be}$ ratio in rain observed during the first half of 1981 is attributable to the 25 th Chinese nuclear explosion of 16 October 1980 (Burchfield et al., 1982; Burchfield and Kuroda, 1983). Note that the South African incident of 22 September 1979, in which a small nuclear weapon was reported to have been tested in the southern hemisphere, had no significant effect on the ${ }^{90} \mathrm{Sr}$ concentrations in rain collected at Fayetteville, Arkansas.

Figure 2 shows that a sharp increase in the ${ }^{210} \mathrm{Po} /{ }^{7} \mathrm{Be}$ ratio in rain occurred toward the end of 1980 and during the months of January and February 1981, which can be attributed to an atmospheric injection of excess ${ }^{210}$ Po by a series of major eruptions of Mount St. Helens, which began on 18 May 1980) (Kuroda et al., 1984). A small peak in the ${ }^{210} \mathrm{Po} /{ }^{7} \mathrm{Be}$ ratio in rain was observed during the winter mounts of 1979 -1980 , which may be attributable to the atmospheric injection of excess ${ }^{210}$ Po from the 

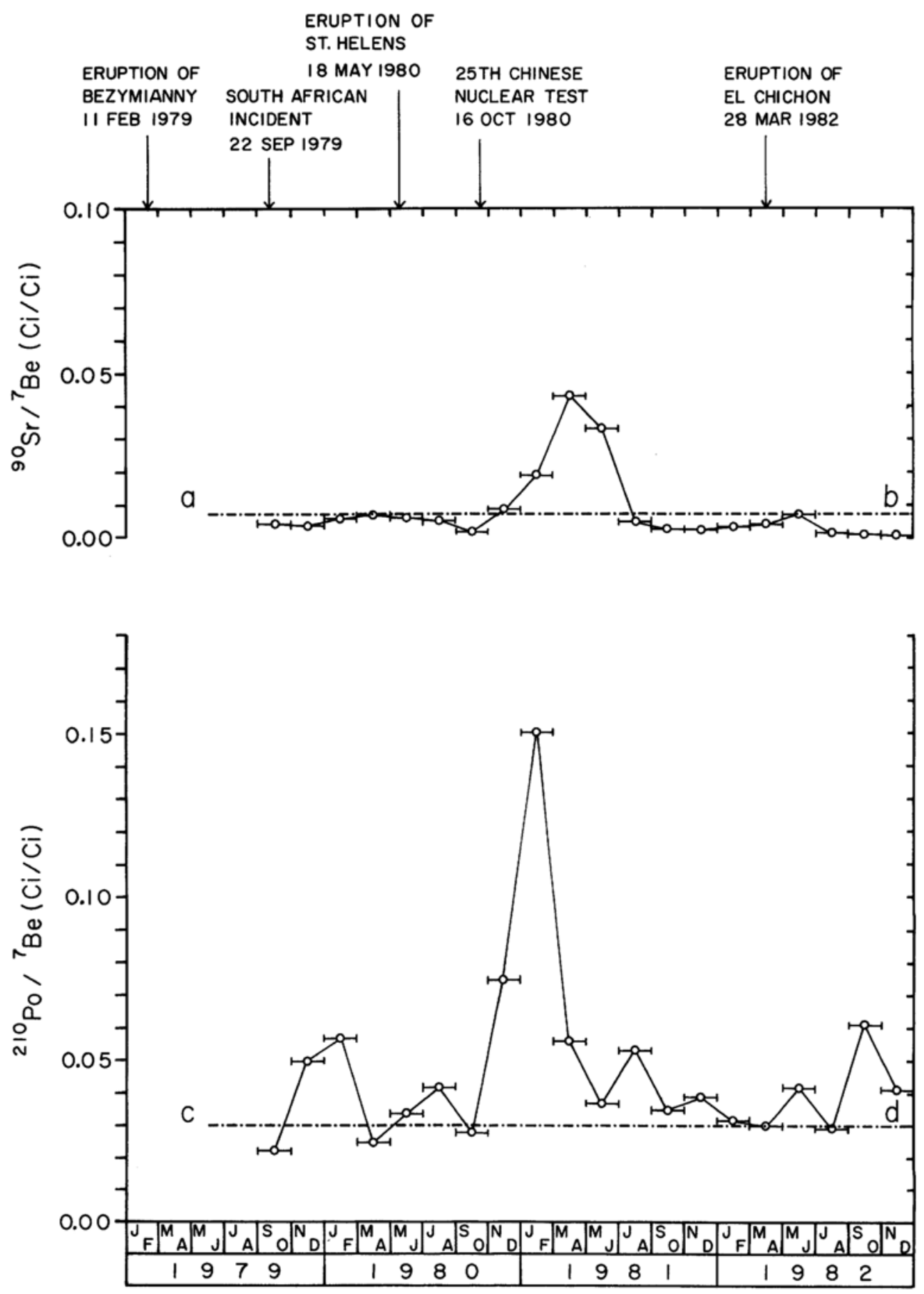

Fig. 2. The ratios of bi-monthly concentrations of ${ }^{90} \mathrm{Sr}$ to ${ }^{7} \mathrm{Be}$ and ${ }^{210} \mathrm{Po}$ to ${ }^{7} \mathrm{Be}$ in rain at Fayetteville, Arkansas, during the period between September 1979 and December 1982. The lines ab and $c d$ show the estimated background values of the ${ }^{90} \mathrm{Sr} /{ }^{7} \mathrm{Be}$ and ${ }^{210} \mathrm{Po} /{ }^{7} \mathrm{Be}$ ratios, respectively, in rain. 
Table 2. Calculations of the values of $F\left({ }^{90} \mathrm{Sr}\right)$ and $F\left({ }^{210} \mathrm{Po}\right)$.

(a) Excess ${ }^{90} \mathrm{Sr}$ from the 16 October 1980 nuclear explosion.

\begin{tabular}{ccccc}
\hline Period & $\begin{array}{c}\left.{ }^{90} \mathrm{Sr} /{ }^{7} \mathrm{Be}\right) \text { obs. } \\
(\mathrm{Ci} / \mathrm{Cl})\end{array}$ & $\begin{array}{c}\delta\left({ }^{90} \mathrm{Sr}\right) \\
(\mathrm{Cl} / \mathrm{Cl})\end{array}$ & $\begin{array}{c}D\left({ }^{7} \mathrm{Be}\right) \\
\left(p C i / \mathrm{cm}^{2}\right)\end{array}$ & $\begin{array}{c}F\left({ }^{90} \mathrm{Sr}\right) \\
\left(p C i / \mathrm{cm}^{2}\right)\end{array}$ \\
\hline 1981 & & & & \\
Jan. -Feb. & 0.019 & 0.012 & 0.1068 & 0.00075 \\
Mar. -Apr. & 0.043 & 0.036 & 0.4191 & 0.01509 \\
May -June & 0.033 & 0.026 & 0.7369 & 0.01916 \\
\hline Total & & & & 0.0350 \\
\hline
\end{tabular}

(b) Excess ${ }^{210}$ Po from the 18 May 1980 eruption of Mount St. Helens

\begin{tabular}{ccccc}
\hline Period & $\begin{array}{c}\left({ }^{210} \mathrm{Po} /{ }^{7} \mathrm{Be}\right) \text { obs. } \\
(\mathrm{Ci} / \mathrm{Cl})\end{array}$ & $\begin{array}{c}\delta\left({ }^{210} \mathrm{Po}\right) \\
(\mathrm{Ci} / \mathrm{Cl})\end{array}$ & $\begin{array}{c}D\left({ }^{7} \mathrm{Be}\right) \\
\left(\mathrm{pCi} / \mathrm{cm}^{2}\right)\end{array}$ & $\begin{array}{c}F\left({ }^{210} \mathrm{Po}\right) \\
\left(\mathrm{pCi} / \mathrm{cm}^{2}\right)\end{array}$ \\
\hline 1980 & & & & \\
May -June & 0.034 & 0.004 & 0.5479 & 0.0022 \\
July -Aug. & 0.042 & 0.012 & 0.0832 & 0.0010 \\
Sep. -Oct. & 0.028 & $(-0.002)$ & 0.3926 & - \\
Nov. -Dec. & 0.075 & 0.045 & 0.1434 & 0.0065 \\
1981 & & & & \\
Jan. -Feb. & 0.150 & 0.120 & 0.1068 & 0.0128 \\
Mar. -Apr. & 0.056 & 0.026 & 0.4191 & 0.0109 \\
May -June & 0.037 & 0.007 & 0.7369 & 0.0052 \\
July -Aug. & 0.053 & 0.023 & 0.4109 & 0.0095 \\
Sep. -Oct. & 0.035 & 0.005 & 0.3028 & 0.0015 \\
Nov. -Dec. & 0.039 & 0.009 & 0.1214 & 0.0011 \\
1982 & & & & \\
Jan. -Feb. & 0.032 & 0.002 & 0.3748 & 0.0008 \\
\hline Total & & & & 0.0515 \\
\hline
\end{tabular}

11 February 1979 eruption of Bezymianny volcano in Kamchatka, U.S.S.R. (Sheng and Kuroda, 1985). The effect of Mount St. Helens on the ${ }^{210} \mathrm{Po} /{ }^{7} \mathrm{Be}$ ratio in rain seems to have ceased at the beginning of 1982 when the ${ }^{210} \mathrm{Po} /$ ${ }^{7} \mathrm{Be}$ ratio in rain decreased to about $0.03(\mathrm{Ci} / \mathrm{Ci})$. A small increase in the ${ }^{210} \mathrm{Po} /{ }^{7} \mathrm{Be}$ ratio in rain observed after the spring of 1982 is most likely due to the 28 March 1982 eruption of E1 Chichon volcano in Mexico.

An order of magnitude calculation of the total amount of excess ${ }^{210} \mathrm{Po}$ from the 1980 eruption of Mount St. Helens can be carried out by the use of the equations

$$
\delta\left({ }^{210} \mathrm{Po}\right)=\left({ }^{210} \mathrm{Po} /{ }^{7} \mathrm{Be}\right)_{\text {obs. }}-\left({ }^{210} \mathrm{Po} /{ }^{7} \mathrm{Be}\right)_{\mathrm{o}}
$$

and

$$
F\left({ }^{210} \mathrm{Po}\right)=D\left({ }^{7} \mathrm{Be}\right) \cdot \delta\left({ }^{210} \mathrm{Po}\right)
$$

where ${ }^{210} \mathrm{Po} /{ }^{7} \mathrm{Be}$ is the ratio of bi-monthly concentrations of ${ }^{210} \mathrm{Po}$ and ${ }^{7} \mathrm{Be}$; the subscripts $o b s$. and $o$ refer to the observed and background values; $D$ is the total amount of ${ }^{7} \mathrm{Be}$ deposition during a two-month period; and $F$ is the total amount of excess ${ }^{210}$ Po which was transported to the ground by rain during the same period. We also have the relationships for ${ }^{90} \mathrm{Sr}$ :

$$
\delta\left({ }^{90} \mathrm{Sr}\right)=\left({ }^{90} \mathrm{Sr} /{ }^{7} \mathrm{Be}\right)_{\text {obs. }}-\left({ }^{90} \mathrm{Sr} /{ }^{7} \mathrm{Be}\right)_{\mathrm{o}}
$$

and

$$
F\left({ }^{90} \mathrm{Sr}\right)=D\left({ }^{7} \mathrm{Be}\right) \cdot \delta\left({ }^{90} \mathrm{Sr}\right)
$$

The values of $\left({ }^{90} \mathrm{Sr} /{ }^{7} \mathrm{Be}\right)_{0}$ and $\left({ }^{210} \mathrm{Po} /{ }^{7} \mathrm{Be}\right)_{0}$ were estimated graphically to be $0.007(\mathrm{Ci} / \mathrm{Ci})$ and $0.03(\mathrm{Ci} / \mathrm{Ci})$, respectively, and are illustrated by the lines $a b$ and $c d$ in Fig. 2. Table 2 shows the results of calculations. The values of $F\left({ }^{90} \mathrm{Sr}\right)$ $=0.035\left(\mathrm{pCi} / \mathrm{cm}^{2}\right)$ and $F\left({ }^{210} \mathrm{Po}\right)=0.052(\mathrm{pCi} /$ $\mathrm{cm}^{2}$ ) are thus obtained for the amounts of excess ${ }^{90} \mathrm{Sr}$ and excess ${ }^{210} \mathrm{Po}$ injected into the atmosphere by the 25 th Chinese nuclear explosion and the 18 May 1980 eruption of Mount St. Helens, respectively. This means that the total amount of excess ${ }^{210}$ Po released from the 1980 eruption of Mount St. Helens was about 1.5 times the amount of ${ }^{90} \mathrm{Sr}$ released from the 16 October 
1980 nuclear explosion. Kuroda et al. (1984) have estimated the total amount of ${ }^{90} \mathrm{Sr}$ injected into the atmosphere by the 16 October 1980 nuclear explosion was about $8 \times 10^{4} \mathrm{Ci}$. They used the values of bi-monthly concentrations of ${ }^{90} \mathrm{Sr},{ }^{210} \mathrm{~Pb}$ and ${ }^{210} \mathrm{Po}$ in rain and found that the total excess ${ }^{210} \mathrm{Po}$ deposition at Fayetteville, Arkansas, caused by the 1980 eruption of Mount St. Helens was about 1.5 times the value of the amount of ${ }^{90} \mathrm{Sr}$ released by the 16 October 1980 nuclear explosion. These results indicate that the total amount of excess ${ }^{210}$ Po released into the atmosphere by the eruption of Mount St. Helens was approximately $8 \times 10^{4} \times 1.5=1.2$ $\times 10^{5} \mathrm{Ci}$.

Acknowledgments-This investigation was supported by the National Science Foundation under grants ATM 82-06718 and ATM 84-07618.

\section{REFERENCES}

Bleichrodt, J. F. and Van Abkoude, E. R. (1963) On the deposition of cosmic-ray-produced beryllium 7 . J. Geophys. Res. 68, 5283-5288.

Buchanan, J. D. (1958) Radiochemical procedure for beryllium. J. Inorg. Nucl. Chem. 7, 140-142.

Burchfield, L. A., Stevens, S., Inn, K. G. W., Sumerlin, N. G. and Kuroda, P. K. (1982) Atmospheric injections of nuclear debris: Strontium 89 and 90 from Chinese weapons tests. J. Geophys. Res. 87, 7273-7278.

Burchfield, L. A. and Kuroda, P. K. (1983) Recent atmospheric injections of nuclear debris: fallout from the 16 October 1980 nuclear explosion. Geochem. J. 17, 63-70.

Crecelius, E. A. (1981) Prediction of marine atmospheric deposition rates using total ${ }^{7} \mathrm{Be}$ deposition velocities. Atmos. Environ. 15, 579-582.

Dukiewicz, V. A. and Husain, L. (1979) Determination of stratospheric ozone at ground level using ${ }^{7} \mathrm{Be} /$ ozone ratios. Geophys. Res. Lett. 6, 171-174.

Furukawa, M. and Kojima, S. (1982) The measurements of airborne radionuclides over Japan since
1974. Applications of nuclear and radio-chemistry, 449-456. Edited by Richard M. Lambrecht and Nabil Morcos, Pergamon Press, New York.

Husain, L., Coffey, P. E., Meyers, R. E. and Cederwall, R. T. (1977) Ozone transport from stratosphere to troposphere. J. Geophys. Res. Lett. 4, 363-365.

Kuroda, P. K., Liou, C. H., Banavali, A. D., Akridge, J. D. and Burchfield, L. A. (1984) Polonium-210 fallout from the 1980 eruption of Mount St. Helens and the mystery cloud of 1982. Geochem. J. 18, $55-60$.

Lal, D. and Peters, B. (1967) Cosmic ray produced radioactivity on the earth. Handbuck der Physik 46, No. 2, 551-612, Edited by K. Sitte. Springer-Verlag: Heidelberg.

Lal, D., Nijampurkar, V. N., Rajagopalan, G. and Somayajulu, B.L.K. (1979) Annual fallout of ${ }^{32} \mathrm{Si}$, ${ }^{210} \mathrm{~Pb},{ }^{22} \mathrm{Na},{ }^{35} \mathrm{~S}$ and ${ }^{7} \mathrm{Be}$ in rains in India. Pro. Indian Acad. Sci. 88A, 29-40.

Matsunami, T., Mizohata, A. and Mamuro, T. (1974) Some attempts to interpret the variations with time of monthly depositions of ${ }^{210} \mathrm{~Pb},{ }^{7} \mathrm{Be},{ }^{137} \mathrm{Cs}$ and ${ }^{144}$ Ce. Ann. Rep. Radiat. Cent. Osaka Prefect. 15, 24-29.

Peirson, D. H. (1963) Beryllium 7 in air and rain. $J$. Geophys. Res. 68, 3831-3832.

Perkins, R. W., Thomas, C. W. and Young, J. A. (1970) Application of short-lived cosmogenic radionuclides as tracer of In cloud scavenging processes. J. Geophys. Res. 75, 3076-3086.

Sheng, Z. Z. and Kuroda, P. K. (1985) Polonium-210 fallout from the 1980 eruption of Mount St. Helens and the mystery cloud of 1982 . Geochem. J. 19, 1-10.

Turekian, K. K., Benninger, L. K. and Dion, E. P. (1983) ${ }^{7} \mathrm{Be}$ and ${ }^{210} \mathrm{~Pb}$ total deposition fluxes at New Haven, Connecticut and at Bermuda. J. Geophys. Res. 88, 5411-5415.

Waiton, A. and Fried, R. E. (1962) The deposition of beryllium 7 and phosphorus 32 in precipitation at north temperate latitudes. J. Geophys. Res. 67, $5335-5340$.

Wogman, N. A., Thomas, C. W., Cooper, J. A. and Engelmann, R. J. (1968) Cosmic ray produced radionuclides as tracers of atmospheric precipitation processes. Science 159, 189-192. 